\title{
Separation, extraction and fractionation of milk protein components
}

\author{
par \\ J. L. MAUBOIS
}

Proteins, unique milk components belonging to genetic patrimony of the various species, are essential nutrients in human diet, especially for newborn. They already represent 20 to $30 \%$ of total dietary proteins in the industrialized world (Hambraeus, 1982) that means how big are, in these countries, conventional uses of milk and its derivatives. It can be predicted that this usual type of milk consumption will be slightly growing in the future ( 1 to $2 \%$ per year according to the country) because of the difference existing in price evolution of animal proteins : milk proteins are 2 to 3 times cheaper than egg or meat proteins, they have a better nutritional value and they are proposed to the consumer in infinite variety of appearances as cheeses. It is obvious that this price difference is seriously taken in consideration by consumers in this actual world economical crisis. Consequently, consumption of conventional dairy products will be increasing not only in the major dairy countries but also in other numerous countries where governments are trying to rise the proportion of animal protein in the diet.

But, it is likely, in the field of new products, that potential openings for milk proteins are the largest, the most diversified and the most able to lead to high valorization. Indeed, thanks to fantastic progresses of knowledge accomplished by dairy Research and also thanks to emergence of extremely acute separation techniques, very well adapted to "biological sensitivity" of these components, dairy industry is now able, and will become more and more in the near future, to produce a large variety of new proteinaceous products corresponding to the needs of down stream industries as food or pharmaceutical industries.

To try to review all the new transformations of milk proteins was the purpose of the present lecture. The attempt was relatively ventured because of the actuality of this topic that meaned some retention and

Dairy Research Laboratory, I.N.R.A., 65, rue de Saint-Brieuc - 35042 Rennes cedex (France).

Ce texte est la traduction en langue anglaise d'une conférence prononcée le 17 octobre 1984, lors de la Journée SESIL-IESIEL. Le texte français est diffusé par les soins de cette association. 


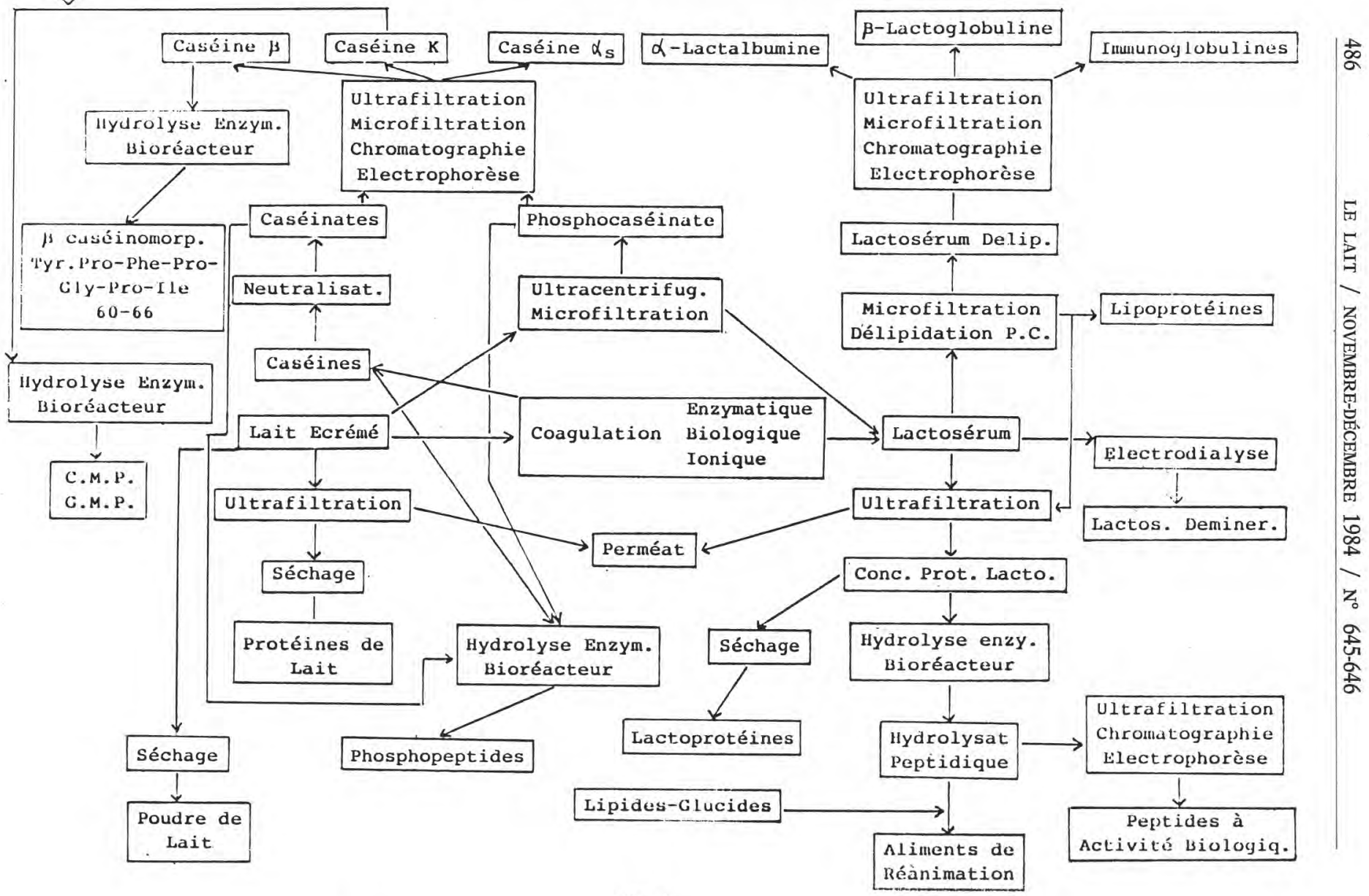

fig. 1

Possible ways of separation and fragmentation of milk proteins. 
even some occultation of informations for obvious reasons of industrial property. Nevertheless, we tried to face the proposed challenge.

Figure 1 represents an attempt to schematize all new possibilities of separation, purification and fragmentation of both milk protein categories : caseins and whey proteins. It does not pretend to be complete and it is not because it only concerns major proteins and obvious technological steps as evaporation and drying are not indicated.

\section{SEPARATION OF WHOLE MILK PROTEINS}

Whole proteins can be isolated from other skimmilk components (lactose - mineral salts - non protein nitrogen) with two techniques based either on simultaneous precipitation of casein and whey proteins under the triple action of a high heat treatment $\left(90^{\circ} \mathrm{C}-1\right.$ to 20 minutes), $\mathrm{pH}$ lowering ( $\mathrm{pH}$ is brought down to $5.8 ; 5.3$ or 4.6$)$ and calcium chloride addition ( 0.03 to $0.2 \%$ ), or on selective retention of protein components by an ultrafiltration membrane.

First process was initiated in USSR but mostly developed in Australia (Muller, 1982). The obtained coprecipitates have a calcium content around 0.5 to $3 \%$ but their solubility is low. Membrane ultrafiltration (figure 2) allows obtention of a large variety of milk protein enriched products with protein content (Nx6,38/T.S.) ranging from $33 \%$

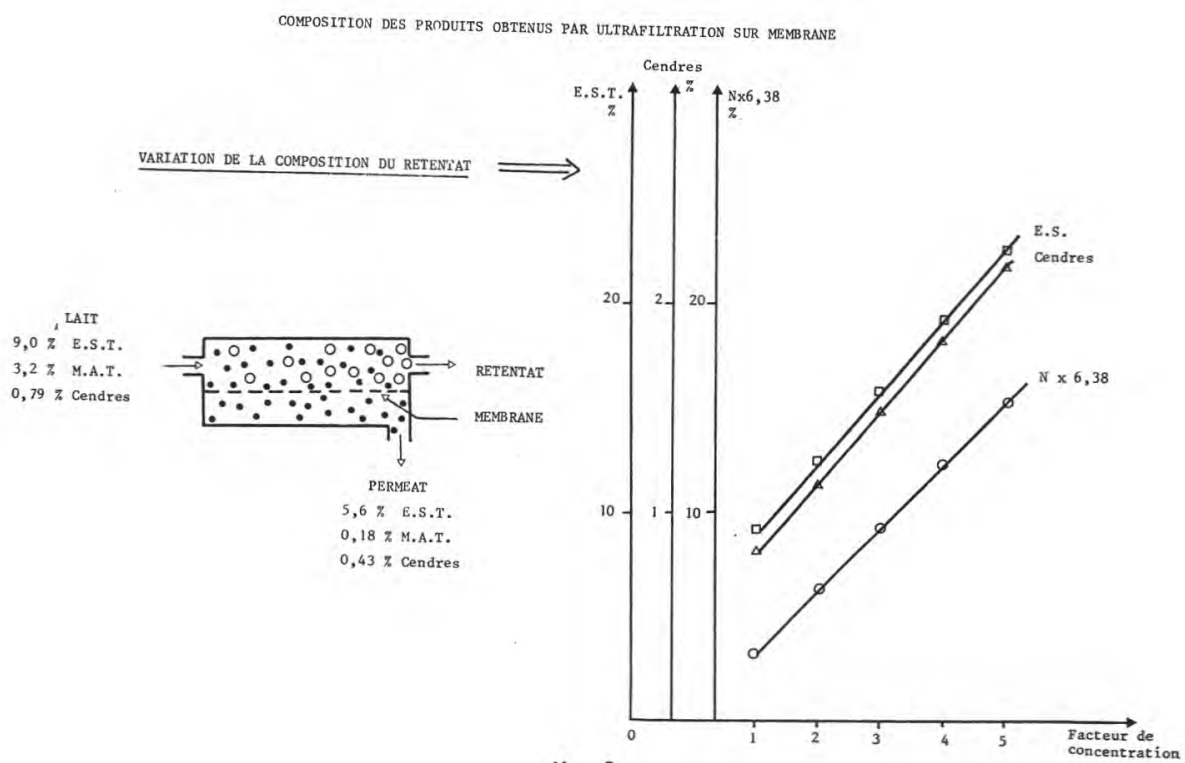

fig. 2

Composition of products obtained through membrane ultrafiltration of skimmilk. 
to $85 \%$, lactose and minerals salts contents practically adjustable as wished by using diafiltration and with a high solubility over a wide $\mathrm{pH}$ range.

\section{SEPARATION OF CASEINS AND WHEY PROTEINS}

Old, actual and future separation techniques of the two major groups of milk proteins can be classified according to the casein property used for its extraction. This extraction technique can be physicochemical, biological or purely physical.

The elderly known technique for casein separation is the physicochemical one. It even supports the casein definition (Gordon and Kaplan, 1972). Lowering milk $\mathrm{pH}$ to 4.6 leads to casein precipitation. The precipitate is washed several times in order to reach a satisfactory degree of purification. All types of acid can be employed as precipitants but the most used ar hydrochloric and sulphuric acids. Because of poor valorization of acid casein wheys, recent techniques of so called ionic acidification (Triballat, 1979 ; Rialland and Barbier, 1980, were recently developed. They are found on exchange of milk cations $\left(\mathrm{Na}^{+}, \mathrm{K}^{+}, \mathrm{Ca}^{+}+\right)$with protons $\left(\mathrm{H}^{+}\right)$brought by ion exchange resins. The resulting wheys have a lower mineral content, especially the ones coming from the Bridel process (Rialland et Barbier, 1980) which do not contain any acid anions. Another advantage of this last process is an increase of casein yield due to the retention in the curd of the main proteose-peptone consequently of an hysteresis effect of solubility of this component (Pierre et Douin, 1984).

Casein separation through biological processes leads to products with very different properties and therefore with different ultimate valorizations. Lactic fermentation allows lactose bioconversion to lactic acid until $\mathrm{pH}$ reduction to 4.6 . The obtained precipitate of casein has similar properties than the ones of acid casein. Addition of rennet to skimmilk allows the splitting of K-casein fraction and so destabilize the casein micelles. Then, coagulation takes place with releasing in the whey of caseinomacropeptide (C.M.P.). The so obtained rennet casein is very mineralized and has all together plastic properties interesting for the sausage industry and stretching abilities used in cheesemaking. When formaldehyde is added before hot pressing, rennet casein precipitate is transformed in a very hard plastic: galalithe.

Separation of casein through physical techniques is still prospective. But, recent progresses in porous materials as those in high mechanical resistance metallic alloys or composite materials will lead to industrial emergence of microfiltration and of ultracentrifugation for separating all different types of casein from skimmilk. Figure 3 schematizes a process for preparing native phosphocaseinate through ultracentrifugation of an ultrafiltration retentate as proposed by Maubois et al. (1974). Very promising results were obtained at laboratory scale regarding to yield 


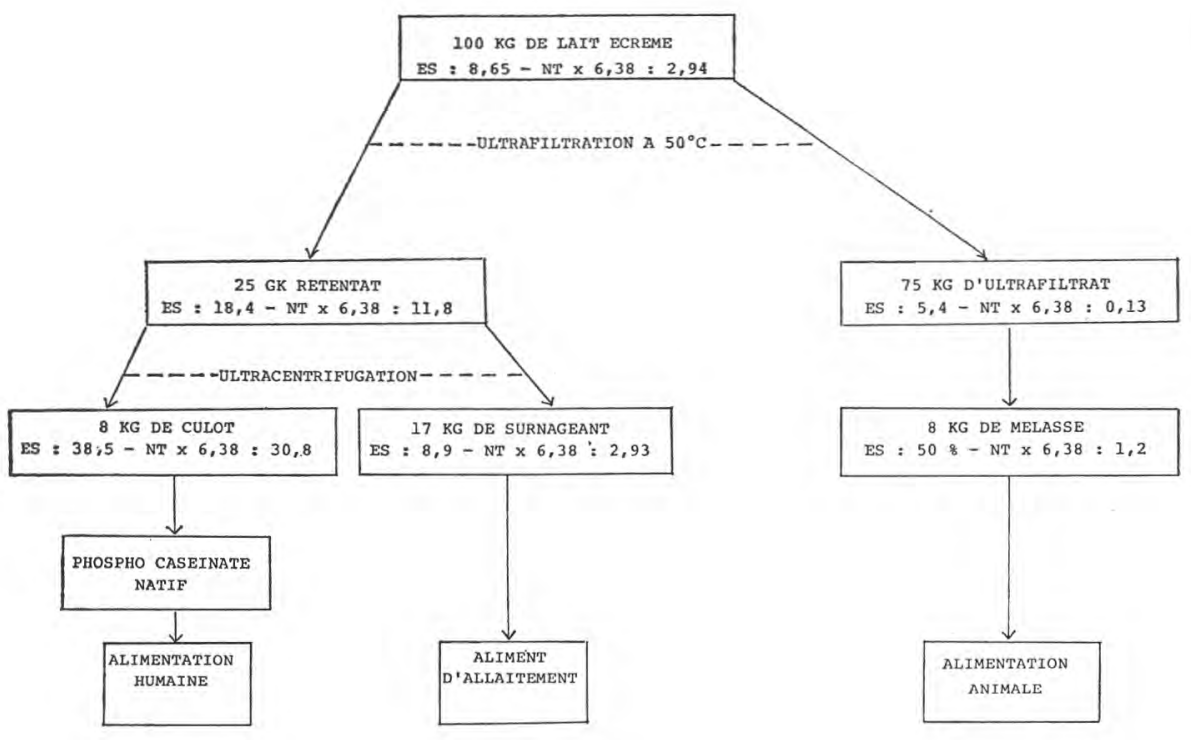

fig. 3

Schema of the process combining ultrafiltration an ultracentrifugation for the production of native phosphocaseinate (MAUBOIs et al., 1974).

(practically equal to theoritical maximum), composition and concentration of sediment and supernatant but equipment manufacturer partner was unable to build the required industrial continuous ultracentrifuge.

Recent commercialization of mineral microfiltration membranes (Veyre, 1984) with pore homogeneity which can be expected either because of use of new ceramic materials $\left(\mathrm{ZrO}_{2}, \mathrm{Al}_{2} \mathrm{O}_{3}, \mathrm{Csi}\right)$ or because of use of high energy radiations for preparing thick screen membranes lead to envisage in the near future, that casein and whey proteins will be industrially separated by these physical techniques.

\section{SEPARATION OF THE DIFFERENT CASEIN SPECIES}

The objectives of such a separation are not based on caseins themselves : $\alpha_{\mathrm{s}}$ casein $46 \% ; \beta$ casein $34 \%$; K-casein $13 \%$ but on the products that they allow to obtain more easily and with higher purity. Casein on which most of the efforts of separation are devoted is $\beta$ casein. Indeed, it could be used as raw material for preparing $\beta$-casomorphin which is an heptapeptide located in $60-66$ position in the sequence. This $\beta$-casomorphin is similar to opiates or is a mediator for their synthesis 
which would play a main role in sleep or hunger regulations and in insuline secretion (Mendy, 1984), that explains interest on this component for dietetic therapy. Industrial separation of $\beta$ casein could be realized in the near future with techniques as microfiltration, ion exchange chromatography or continuous electrophoresis. Fragmentation in enzymatic membrane reactor could be easy but isolation of $\beta$ casomorphin will require carrying out of new separation techniques, probably chromatography or electrophoresis.

Other casein fragments will eventually be interesting to isolate either for their nutritional or even physiological properties, or for their functional properties. Recently, Shimizu et al. (1984) indicated that $\mathrm{N}$-terminal extremity (1-23) of $\alpha$.sicasein had very good emulsifying activity and could be easily separated from a peptic hydrolysate through centrifugation.

\section{SEPARATION OF ORIGINAL SEQUENCES OF CASEIN}

Presence of phophoserine residues gives to milk caseins a very marked chelating power versus calcium ions and trace elements. Physico-chemical characteristics of native calcium phosphocaseinates lead to envisage that phosphopeptidic residues play a essential role in casein micelle stability, in mechanismes governing gel formation during coagulation and also in intestinal absorption of minerals and trace elements. These considerations led Brule et al. (1980) to imagine two patented processes for purifying these original casein sequences (figure 4). Isolation of these products from peptidic hydrolysates is based on their chelating properties. Indeed, when calcium and phosphate ions are present in the solution, these peptides aggregate and so, can be purified with membrane ultrafiltration technique, non phosphorylated peptides going through the UF membrane. The sequestrating power of the so obtained products is very high. $100 \mathrm{~g}$ can fix 5.6 of calcium, $10 \mathrm{~g}$ of copper, $5 \mathrm{~g}$ of zinc, $12 \mathrm{~g}$ of $\mathrm{Fe}^{++}$or $5 \mathrm{~g}$ of $\mathrm{Fe}^{+++}$. That leads to envisage very large and diversified potential markets for phosphopeptidic products and maybe, there is some possibility that European milk production will be not enough for facing the demand in five or ten years.

\section{SEPARATION OF THE WHOLE WHEY PROTEINS}

Whey is a dilute fluid containing 4 to $6 \mathrm{~g}$ of true proteins per liter. These proteins have excellent functional properties and a very high nutritional value due to their exceptional content in sulphur amino-acids, in lysine and in tryptophane. Extraction of these proteins for the purpose of human nutrition is not a new finality because such a thing was 


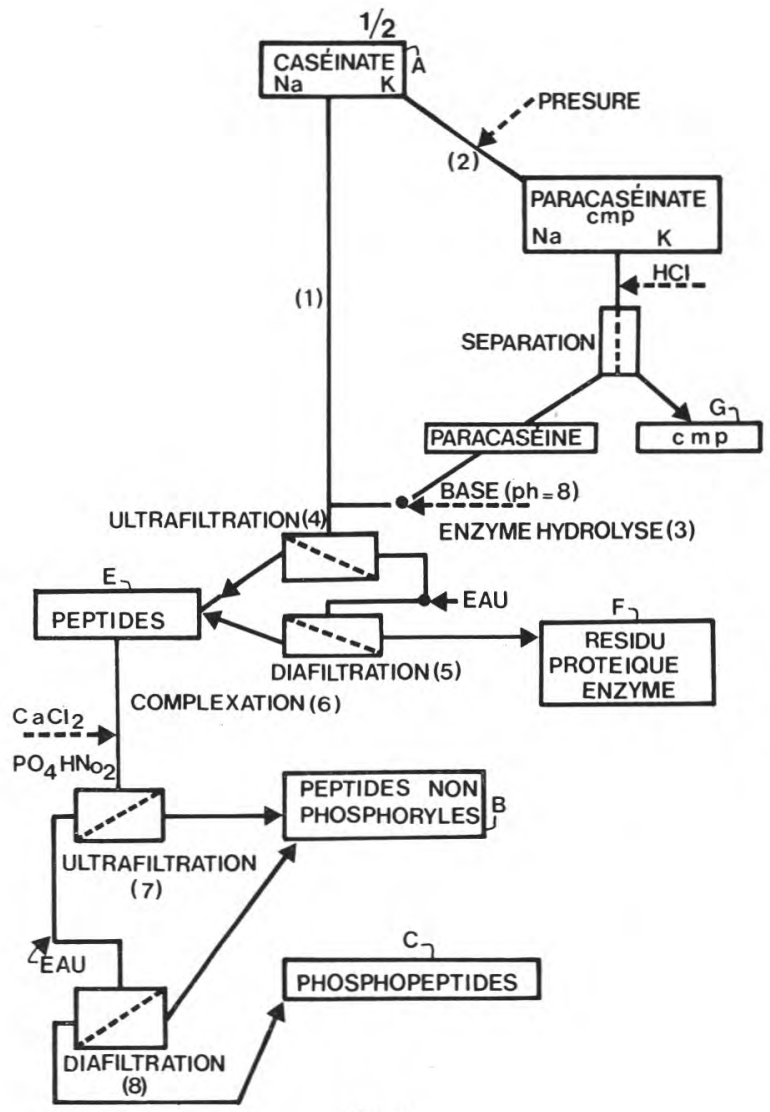

fig. 4

Schema of the preparation of phosphopeptides from caseinate (BRULÉ et al., 1980).

Schéma de préparation de phosphopeptides à partie de caséinates (BRULÉ et al., 1980).

already realized during making of old whey cheeses as Serac or Bruccio. But, is was only at the beginning of the Seventies that, with the development of membrane ultrafiltration, a true new whey industry was born for preparing very diversified whey protein products required by downstream food industries (Maubois, 1982).

Membrane ultrafiltration offers possibility to prepare a large range of whey protein concentrates (W.P.C.) with protein content from 35 to $85 \%$. The main functional advantages of W.P.C. are :

- solubility all over the $\mathrm{pH}$ scale, 
- high water retention capacity,

— gelification ability,

— foaming ability.

Mainly, cheese wheys, but also casein wheys in a lower degree, contain residual non centrifugeable lipids which are responsible of opalescence of the liquid. Most of these residual lipids are phospholipoproteins (sphingomyeline, phosphatidylcholine and phosphatidylethanolamine) coming from the fat globule membranes. Concentrated at the same rate than proteins during ultrafiltration, their presence in W.P.C. can limit market openings for some utilizations as the ones taking advantages of foaming functionality. They are also limiting ultrafiltration fluxes and efficiency of downstream fractionations and fragmentations. These lipoproteins could be specifically separated on industrial scale, in the near future, either by using microfiltration technique as proposed by Piot $e t$ al. (1984) or by using physico-chemical processes as the one recently developed by Fauquant et al. (1985) and which is based on aggregation of lipoproteins during a moderate heat treatment in presence of calcium ions. Valorization of these so-extracted lipoproteins will be easy because of their excellent emulsifying capacities.

Removal of whey residual lipids is, for us, strictly necessary before any trying of separation of whey proteins through chromatography. It is probably because this absolutely required step was not observed that industrial scale-up of Spherosil RP process has met so known difficulties. Indeed, whey lipoproteins have very marked amphoteric and amphiphilic characteristics which lead to a strong adsorption on all porous materials. Consequently, this adsorption brings fouling or even "poisoning" of ion exchange resins which becomes irremediable because of physico-chemical limits of cleaning acceptable by these materials. Application of anion exchange chromatography to defatted whey could allow, at the beginning, secure preparation of W.P.C. with a protein/T.S. ration near 90-95\% (Malige, 1982) then by varying eluting conditions (use of $\mathrm{pH}$ or ionic strength gradients for example) obtention of the different whey proteins.

\section{SEPARATION OF THE DIFFERENT WHEY PROTEINS}

Beyond the aforementioned ion exchange chromatography, it can be envisaged to separate the individual whey proteins through techniques based on their differences in electrical charge as electrophoresis or in molecular size as ultrafiltration or microfiltration. These last techniques have led to very promising results regarding to separation of immunoglobulins and $\alpha$-lactalbumin enriched fractions (Roger et Maubois, 1981).

Separation of immunoglobulins finds its purpose in applications for protecting intestinal tractus of the young calf ; separation of $\alpha$-lact- 
albumin in the exceptional high tryptophane content of this protein (4 residues per mol). Such a protein could allow preparation of tryptophane containing peptides which could be used as precursors of serotonine (neuropeptide which regulates sleep and hunger [Mendy et al., 1981]).

\section{FRAGMENTATION OF WHEY PROTEINS}

Because of their high nutritional value, whey proteins can constitute all the proteic part in dietetic therapy. But. formulation of the product requires that the nutrients so brought through enteral way to patients suffering of major intestinal diseases, have an analog structure to the one of metabolites arriving in human intestine after a normal digestion. That implies to realize, outside of human organism, limited operations

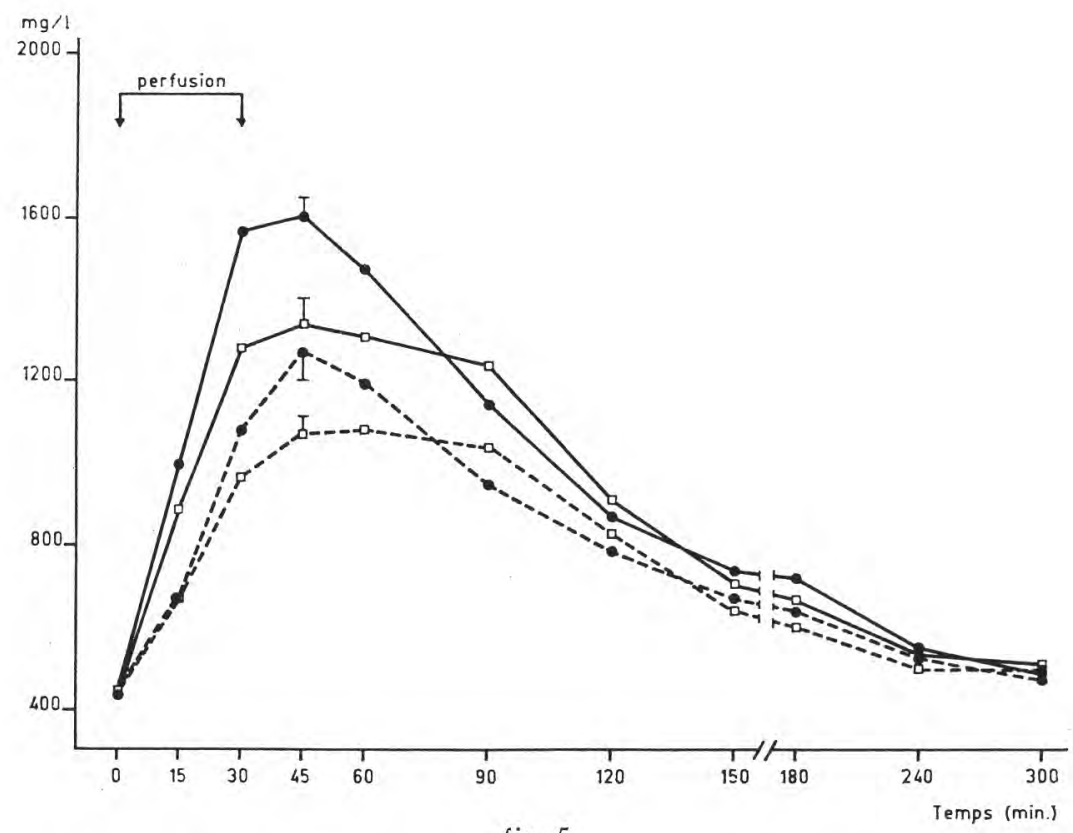

fig. 5

Evolution of $\alpha$ amine nitrogen in portal blood $(-)$ and in carotid blood (--) after perfusion of $55 \mathrm{~g}$ of whey protein enzymatic hydrolysate (•) and of $55 \mathrm{~g}$ of amino acids (口) (RÉRAT et al., 1984).

Concentration en azote $\alpha$ aminé dans le sang portal $(\longrightarrow$ et dans le sang carotidien (--) après perfusion de $55 \mathrm{~g}$ d'un hydrolysat enzymatique (chymotrypsine-trypsine) de protéines laitières $(\bullet)$ et de $55 \mathrm{~g}$ d'acides aminés ( $\square$ ) (RÉRAT et al., 1984). 
of digestion which cannot be accomplished by the patient. Such a simulation of proteic digestion can be carried out by using enzymic membrane reactor technology (Maubois et Brule, 1982). The products leaving the reactor contain peptidic sequences able to allow not only an optimum absorption (figure 5) (Rerat et al., 1984), but also to start, directly from intestinal receptors, operations of anticipating regulation (hormonal and enzymic secretions - guidance of metabolic crossroads). A regeneration or a compensatory hypertrophy of missing intestinal segments can be produced thanks to this type of feeding (Mendy, 1984). Fragmentation of milk proteins, collaboratively studied by Sopharga Society and our INRA laboratory is now a commercial reality (Reabilan is the trade name of the product) and the production will be scaled up until several hundred tons next year.

\section{CONCLUSIONS - PERSPECTIVES}

Already available separation techniques, those which will become in the near future offer to dairy technologists fantastic tools for separating, fractionating, fragmentating the most interesting milk components for human feeding i.e. proteins. It is, in this field of "proteic cracking" that dairy industry will take an important part of the 200 billions dollars market announced for biotechnologies at the beginning of the third millenary. It has abilities because of the deep knowledge of its raw material, milk, because of the advanced technicity of its equipments and because of the skillness of its professionals. But, it is necessary that dairy industry will want constantly to go ahead through continuous innovations not only in a specifically dairy market but chiefly in a planetary context of glucidic, lipidic and proteic components market and that, in tight collaboration with downstream industrial sectors.

\section{References}

Brulé (G.), Roger (L.), Fauquant (J.) et Piot (M.) (1980). - Procédé de traitement d'une matière à base de caséine contenant des phosphocaséinates de cations monovalents et leurs dérivés. Produits obtenus et applications. Brevet français $\mathrm{n}^{\circ} 8002281$.

Fauquant (J.), Vieco (E.) et Brulé (G.) (1985). - Clarification physico-chimique des lactosérums de fromagerie. Le Lait (soumis pour publication).

Gordon (W.G.) and KaLAN (E.B.) (1974). - Proteins of milk. Fundamentals in Dairy Chemistry 2nd. Ed. By B.H. Webb, A.H. Johnson and J,A. Alford (Eds) Avi Publ. Co Westport, p. 87-124.

Hambraeus (L.) (1982), - Nutritional aspects of milk proteins in Developments in Dairy Chemistry. 1. Proteins. Ed. by P.F. Fox, Appl. Sc. Publ., London, p. 289.

MaLige (B.) (1982). - Les protéines de lactosérum extraites par chromatographie. Protéines animales. Ed. C.M. Bourgeois et P. Le Roux. Techn. Docum. Lavoisier, Paris, p. 191-201. 
Maubois (J.L.), Fauquant (J.) et Brulé (G.) (1974). - Procédé de traitement de matières contenant des protéines telles que le lait. Brevet français n 7439311.

Maubois (J.L.) (1982). - Les protéines de lactosérum extraites par ultrafiltration. Protéines animales. Ed. C.M. Bourgeois et P. Le Roux. Techn. Docum. Lavoisier, Paris, p. 172-190.

MAUbois (J.L.) et BRULÉ (G.) (1982). - Utilisation des techniques à membrane pour la séparation, la purification et la fragmentation des protéines laitières. Lait, 62, 484-510.

Mendy (F.), Brachfogel (N.) et Spielmann (D.) (1981). - Actualités dans le domaine de la connaissance, de l'utilisation digestive et métabolique en nutrition humaine des protéines laitières. Rev. Lait. Franç., 400, 37-58.

MENDy (F.) (1984). - Fragmentation des protéines laitières. Biofutur, 24, 60-61. Interview de J. Rajnchapel-Messai.

MUlLER (L.L.) (1982). - Manufacture of casein, caseinates and coprecipitates in developments in Dairy Chemistry. 1. Proteins. Ed. by P.F. Fox., Appl. Sc. Publ., London, p. 315.

Pierre (A.) et Douin (M.) (1984). - Eléments d'étude du procédé Bridel de fabrication de caséine à partir de lait décationisé par échanges d'ions (E.I.), Le Lait, 64, 521-536.

Piot (M.), Maubois (J.L.), Schaegis (P.), Veyre (R.) et Luccioni (M.) (1984). Microfiltration en flux tangentiel des lactosérums de fromagerie. Le Lait, 64, 102-120.

Rerat (A.), Lacroix (M.), Simoes-Munes (C.), Vaugelade (P.) et Vaissade (P.) (1984). - Absorption intestinale comparée d'un mélange d'hydrolysats ménagés de protéines laitières et d'un mélange d'acides aminés libres de même composition chez le porc éveillé. Bull. Acad. Nat. Méd., 168, 385-391.

Rialland (J.P.) et BarbieR (J.P.) (1980). - Procédé de traitement du lait sur une résine échangeuse de cations en vue de la fabrication de la caséine et du lactosérum. Brevet français $\mathrm{n}^{\circ} 2480568$.

Roger (L.) et Maubors (J.L.) (1981). - Actualités dans le domaine des technologies à membrane pour la préparation et la séparation des protéines laitières. Rev. Lait. Franç., 400, 67-75.

Shimizu (M.), Lee (S.W.), Kaminogawa (S.) and Yamauchi (K.) (1984). - Emulsifying properties of an $\mathrm{N}$-terminal peptide obtained from the peptic hydrolyzate of $\alpha_{\mathrm{s} 1}$-casein. $J$. Food $S c ., 49,1117$.

Triballat ( ) (1979). - Procédé et installation pour la préparation de la caséine à partir du lait et produits ainsi obtenus. Brevet français $n^{\circ} 2428626$.

VeYre (R.) (1984). - Utilisation des membranes minérales Carbosep en industrie agro-alimentaire. Le Lait, 64, 261-275. 